\title{
论 文
}

\section{准噶尔盆地南缘泥火山天然气的地球化学特征}

\author{
戴金星", 吴小奇, 倪云燕, 汪泽成, 赵长毅, 王兆云, 刘桂侠 \\ 中国石油勘探开发研究院, 北京 100083 \\ * E-mail: djx@ @etrochina.com.cn
}

收稿日期: 2011-03-30; 接受日期: 2011-09-05

\begin{abstract}
摘要我国准噶尔盆地南缘发育多处泥火山, 1991 年 6 月和 2010 年 8 月, 两次对准噶尔 盆地南缘泥火山进行考察. 从气压减小、出气量减少、泥浆池口陷落和泥浆池干涸等变化, 可见泥火山活动渐趋衰弱, 活动强度明显小于中国台湾一些泥火山. 泥火山天然气具有相 似的地球化学特征, 表明其具有同源性或同因性. 泥火山天然气主要组分是烷烃气, 含量为 $91.15 \%$ 97.49\%, 其中甲烷含量最高, 是优质商业气; 天然气 $\delta^{13} \mathrm{C}_{1}$ 值为 $-49.1 \%$ - $40.6 \%$, 与 世界范围内泥火山气 $\delta^{13} \mathrm{C}_{1}$ 频率高峰段一致, 且烷烃气碳同位素系列具有 $\delta^{13} \mathrm{C}_{1}<\delta^{13} \mathrm{C}_{2}<\delta{ }^{13} \mathrm{C}_{3}$ 特征, 是典型热成因气; 研究区泥火山气具有较低的 ${ }^{3} \mathrm{He} /{ }^{4} \mathrm{He}$ 值, $R / R \mathrm{a}$ 为 $0.011 \sim 0.054$, 属典型壳源氦; 泥火山天然气的 $\delta^{13} \mathrm{C}_{2}$ 值均大于 $-28 \%$, 是典型煤成气, 且 $\mathrm{C}_{1} / \mathrm{C}_{1-4}$ 和 $\delta^{13} \mathrm{C}_{1}$ 值两指标与该盆地下中侏罗统源岩形成的煤成气特征一致, 因此, 准噶尔盆 地南缘泥火山烷烃气的气源主要是下中侏罗统煤系源岩.
\end{abstract}

关键词

准噶尔盆地

泥火山

天然气

地球化学特征

气源
泥火山又称假火山, 是夹带着水、泥、砂和岩 屑的地下天然气体, 在压力作用下不断的喷出地表 所堆成的泥丘, 它是特定地质构造及水文地质环境 下的一种构造流体地质现象. 泥火山的成因大致可 以分为两类: 一种泥火山的形成与沉积作用有关, 这类泥火山在世界泥火山中占绝大多数, 多发育在 油气藏发育地区, 如阿塞拜疆巴库地区的泥火山; 另一种泥火山的形成则与火山活动有关, 这类泥火 山较少. 典型的如在美国的黄石公园 ${ }^{[1]}$ 以及新西兰. 沉积类泥火山的形成需要以下条件：(1) 近期的构 造活动特别是挤压作用; (2) 沉积或构造载荷导致 快速沉积、增生或逆冲; (3) 烃类的连续产生; (4) 沉 积层序上深部存在厚层、细粒、柔软和塑性的沉积 物 $^{[2]}$.
从全球而言, 泥火山在海底和陆上均有分布, 尽管泥火山可以发育于不同的构造环境, 但大多数 位于挤压构造背景, 其中陆上泥火山主要沿着加勒 比-太平洋带、喜马拉雅-阿尔卑斯造山带和中亚造山 带分布, 而海底泥火山则在活动大陆边缘和被动大 陆边缘均有分布 ${ }^{[3-5]} .2002$ 年全世界已发现的陆上和 海底泥火山分别超过 900 个和 800 个 $^{[2]}$. 阿塞拜疆南 里海盆地巴库地区是世界上泥火山分布最为密集的 地区, 目前已发现活动的泥火山(陆上和海底均有) 超过 400 个 $^{[6]}$. 一般泥火山活动没有造成大的灾害, 但印度尼西亚东爪哇的“LUSI”泥火山, 不仅是世界 上最大的灾害极大的并且喷发速率最快的泥火山, 其覆盖范围达 $7 \mathrm{~km}^{2}$, 导致 13000 个家庭失去家园 ${ }^{[7]}$. 自从 2006 年 5 月 29 日喷发以来, 每天喷发出的泥

英文引用格式: Dai J X, Wu X Q, Ni Y Y, et al. Geochemical characteristics of natural gas from mud volcanoes in the southern Junggar Basin. Sci China Earth Sci, 2012, doi: 10.1007/s11430-012-4363-x 
浆超过 $100000 \mathrm{~m}^{3[8]}$, 预计该泥火山还将喷发超过 26 年 ${ }^{[7]}$.

据 1986 年初步统计, 我国已知的泥火山至少有 200 余处 $^{[9]}$, 尽管在四川盆地渠江一带 ${ }^{[10]}$ 、青藏高原 可可西里地区 ${ }^{[11]}$ 、青海柴达木盆地和江苏南部 ${ }^{[9]}$ 均有 发现, 但主要还是分布在中国台湾、新疆北部和藏北 芫塘, 前人的关注也相对较多. Yang 等 ${ }^{[12] 、}$ 、朱婷婷等 ${ }^{[13]}$ 和 Sun 等 ${ }^{[14]}$ 对台湾泥火山气体的组分、同位素组成和 喷出速率及泥火山的形成机制等进行了分析. 新疆 的泥火山主要分布在北天山地区, 均位于准噶尔盆 地南缘山前坳陷带 ${ }^{[15,16]}$. 最近在青藏高原北部㒸塘 中部也发现了泥火山, 泥火山喷出物中含沥青脉岩 石的发现说明㒸塘新生代沉积盆地具有良好的油气 前景 ${ }^{[17]}$. 尽管分布在新疆乌苏西南天山北麓山谷里 的泥火山群曾被认为是亚洲最大的泥火山群 ${ }^{[18]}$, 但 根据解超明等 ${ }^{\left[{ }^{[7]}\right.}$ 的研究, 藏北㒸塘中部的泥火山分 布规模、喷口直径、泥丘高度等均要超过乌苏泥火山.

近年来对泥火山的研究取得了以下主要进展:

(1) 海底天然气水合物常与泥火山有关 ${ }^{[19,20]}$, 尽 管并不是所有海底泥火山处都发育天然气水合物; 泥火山中部的天然气水合物的形成是水和甲烷渗滤 驱动的过程, 而泥火山外围的天然气水合物则主要 来自甲烷扩散和与水混合所驱动; 初步估计全球与 泥火山相关的天然气水合物中聚集的 $\mathrm{CH}_{4}$ 总量在常 温常压下大约为 $n \times 10^{10} \sim 10^{12} \mathrm{~m}^{3[19]}$.

(2) 绝大部分泥火山喷出气体以 $\mathrm{CH}_{4}$ 为主, 小部 分泥火山的以 $\mathrm{CO}_{2}$ 或 $\mathrm{N}_{2}$ 为主 ${ }^{[2]}$. 泥火山是大气甲烷 的重要来源之一 ${ }^{[21]}$, 每年通过泥火山向大气中排放 的甲烷总量可达 $(6 \sim 9) \times 10^{6} \mathrm{t}^{[21]}$ 或(10.3 12.6) $\times 10^{6} \mathrm{t}^{[2]}$ 或 $33 \times 10^{6} \mathrm{t}^{[22]}$, 而这种排放对全球气候变化的影响可 能从古生代就开始了 ${ }^{[3]}$, 因此在估算全球大气甲烷总 量时不可忽略 ${ }^{[2,21]}$.

(3) 由于泥火山的出现通常与油气藏的分布有 关, 因此二者关系常引起业内的关注 ${ }^{[23,24]}$, 泥火山排 放出的气体可以为勘探沉积盆地的油气潜力提供有 益的信息 ${ }^{[18]}$, 如阿塞拜疆南里海盆地泥火山分布表 明与油气田有关 ${ }^{[25,26]}$, 新疆独山子泥火山也被认为 与独山子油气田有紧密联系 ${ }^{[16]}$, 台西南盆地泥火山 与油气运聚有着紧密联系 ${ }^{[27]}$.

（4）由于断裂和裂隙等是泥浆和气体上升的通道, 因此泥火山常沿这些构造软弱带发育 ${ }^{[12 ~ 14,17,19,28 ~ 30] . ~}$ 泥火山是深埋沉积物最重要的排气通道 ${ }^{[2]}$, 全球陆上
泥火山中约 $76 \%$ 排放出的气体为热成因气, 排出生 物气和混合气的泥火山分别仅占 $4 \%$ 和 $20 \%{ }^{[31]}$. 分析 泥火山气体的组分和同位素特征可以为研究深埋沉 积物和油气资源提供有益的信息.

除中国台湾外, 中国大陆对泥火山的研究往往 从基础地质的角度出发, 描述其形态和活动状况, 缺 乏对泥火山天然气的系统研究. 解超明等 ${ }^{[17]}$ 对藏北 芫塘中部的泥火山的分布特征、喷发物中的沥青脉等 进行了探讨, 但未采集泥火山的气体. 就新疆地区泥 火山而言, 彭希龄 ${ }^{[16]}$ 对其分布和地貌特征等进行了 总结; 王道等 ${ }^{[32]}$ 初步研究了独山子泥火山喷发的特 征; 高小其等 ${ }^{[33]}$ 研究发现, 新疆霍尔果斯泥火山活 动与新疆地区中强以上地震的活动具有较好的对应 关系, 且对预测未来地震的发震时间及震级都有一 定的指导意义. 但目前尚没有对该区泥火山天然气 分析研究的报道. 本次工作拟通过分析北疆地区泥 火山天然气的组分和同位素特征, 来探讨其成因和 气源, 并通过分析其与准噶尔盆地南缘油气藏的关 系, 为寻找有利的油气勘探领域提供有益的信息.

\section{1 泥火山地质与景观}

泥火山分布在新疆准噶尔盆地南缘, 该区在构 造上属于北天山山前坳陷, 其形成演化与北天山造 山带紧密相关. 受不同强度变形和不同动力来源的 影响, 准噶尔盆地南缘分布多个背斜, 其中泥火山主 要分布在独山子、霍尔果斯、齐古等背斜和托斯台背 斜群的冒烟山、北阿尔钦沟、马东刹拉等背斜上. 目 前, 准噶尔南缘部分泥火山如霍尔果斯泥火山等已经 停喷. 笔者 1991 年和 2010 年先后考察了独山子、冒 烟沟、马东刹拉和阿尔钦沟相关泥火山(图 1,2).

独山子泥火山位于独山子油矿市区南侧的背斜 顶部山头上(图 2(a)), 独山子油气田是根据泥火山标 志经勘探发现的. 该泥火山喷发初期有过爆发阶段, 后转入了宁静的泥水气泉喷发阶段, 随着油田的开发 泄压, 泥火山活动日趋衰弱 ${ }^{[16]} .1991$ 年考察时, 据新 疆油田高级工程师范光华介绍, 1958 年前独山子泥火 山锥状地貌明显, 由于大炼钢铁把泥火山锥铲平了, 有的充填了. 目前, 该区仅有两处活的泥火山喷口, 二者相距约 $100 \mathrm{~m}$, 其中位于西北部的泥火山为雉状 (图 3(a), (b)), 而位于东南侧的则呈坑状(图 3(c)). 泥火 山处出露地层为塔西河组, 泥火山有关参数见表 1 . 


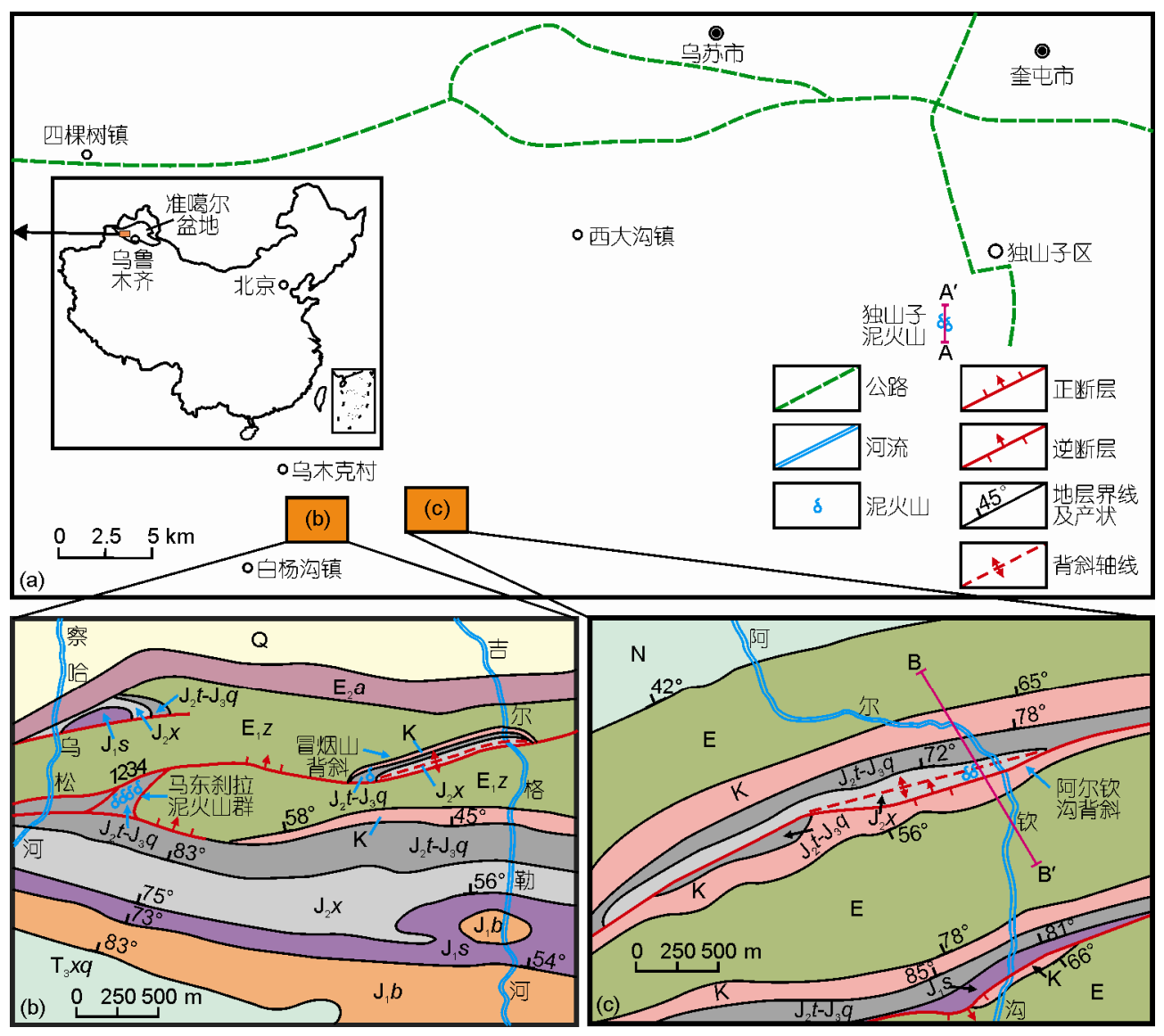

图 1 准噶尔盆地南缘泥火山(a)和马东刹拉和冒烟沟泥火山(b)、阿尔钦沟泥火山(c)位置图
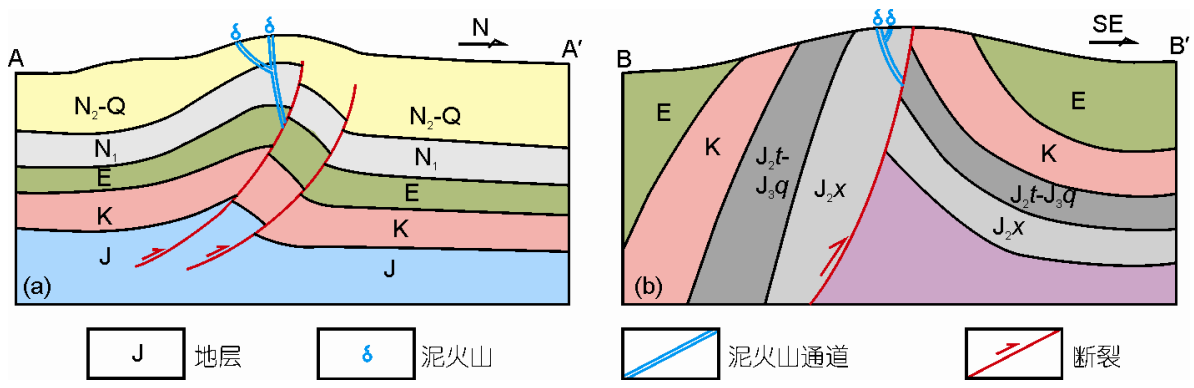

图 2 过独山子泥火山南北向剖面(a)和阿尔钦沟泥火山剖面(b)示意图

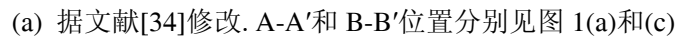

马东刹拉泥火山位于乌苏市四棵树煤矿区察哈 乌松河东岸山坡上，处于侏罗系逆冲到古近系安集 海河组泥岩上 ${ }^{[16]}$. 该区总共有 20 多个泥火山集中分 布在 $500 \mathrm{~m}$ 范围内, 泥火山喷气, 大小不一, 喷出物 中水多泥少，部分泥火山喷出物中有油花. 2010 年从 西向东近 $200 \mathrm{~m}$ 内取了 4 个 $(1,2,3,4)$ 泥火山气样(图 1(b), 图 4, 表 1).
冒烟沟泥火山位于吉尔格勒河之西 $1 \mathrm{~km}$ 冒烟山 北坡的西段(图 1(b)), 有一片小的芦苇地. 区域内有 20 多个冒气口, 大部分泥火山口已经干涸、停喷(图 $5)$, 泥火山有关参数见表 1 .

阿尔钦沟泥火山位于北阿尔钦沟背斜轴部的断 层线上(图 2(b)), 有两个锥状孪生泥火山坐落在河谷 的沙石阶地上, 二者相距约 $10 \mathrm{~m}$, 形态完整(图 6), 

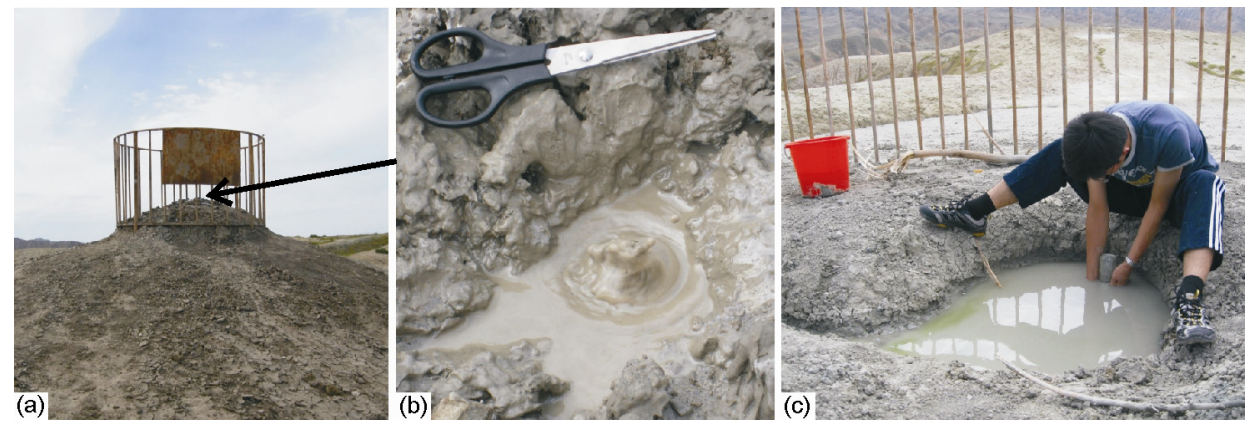

图 3 独山子西北泥火山((a), (b))和东南泥火山喷口 (c)

位置见图 1(a)

表 1 准噶尔盆地南缘泥火山产状和喷气特征(2010 年考察结果)

\begin{tabular}{|c|c|c|c|c|c|c|c|}
\hline 泥火山 & $\begin{array}{l}\text { 泥火山口 } \\
\text { 长轴 }(\mathrm{m})\end{array}$ & $\begin{array}{l}\text { 泥火山口 } \\
\text { 短轴 }(\mathrm{m})\end{array}$ & 形状 & 描述 & $\begin{array}{l}\text { 气泡最大 } \\
\text { 直径 }(\mathrm{cm})\end{array}$ & $\begin{array}{l}\text { 采样 } 250 \mathrm{~mL} \\
\text { 耗时(s) }\end{array}$ & $\begin{array}{c}\text { 估算年喷气 } \\
\left(\mathrm{m}^{3}\right)\end{array}$ \\
\hline 独山子西北 & 0.1 & 0.08 & 雉状 & $\begin{array}{c}\text { 雉高近 } 3 \mathrm{~m}, \text { 喷出物多为泥浆, 水少, } \\
\text { 呈粘稠状, 间歇状冒气 }\end{array}$ & 7 & 40 & 197 \\
\hline 独山子东南 & 1.0 & 0.8 & 坑状 & $\begin{array}{c}\text { 喷出物中水多泥少, 间歇状冒气, } \\
\text { 有两处冒泡 }\end{array}$ & 6 & 660 & 24 \\
\hline 马东刹拉 1 & 3.0 & 1.6 & 坑状 & $\begin{array}{c}\text { 气泡不在火山口中心, 连续冒气, 一个大气 } \\
\text { 泡伴随多个小气泡, 有油花 }\end{array}$ & 25 & 30 & 263 \\
\hline 马东刹拉 2 & 1.1 & 1.0 & 坑状 & $\begin{array}{l}\text { 气泡大的直径约 } 10 \mathrm{~cm} \text {, 小的 } 1 \mathrm{~cm} \text {, 连续冒 } \\
\text { 气, 坑内有三处冒泡. 水多, 有一些油花 } \\
\text { 中心有大气泡, 直径约 } 15 \mathrm{~cm} \text {, 边缘有 }\end{array}$ & 10 & 100 & 110 \\
\hline 马东刹拉 3 & 1.3 & 1.0 & 坑状 & $\begin{array}{c}\text { 小气泡, 直径约 } 6 \sim 7 \mathrm{~cm} . \text { 水多, 泥较多, } \\
\text { 几乎没有油花 }\end{array}$ & 15 & 40 & 394 \\
\hline 马东刹拉 4 & 2.3 & 2.0 & 坑状 & $\begin{array}{c}\text { 水多, 有两处冒泡, 气泡大的直径 } 15 \mathrm{~cm} \text {, 连 } \\
\text { 续冒泡, 油花较少 }\end{array}$ & 15 & 50 & 473 \\
\hline 冒烟沟 & 1.6 & 1.5 & 坑状 & $\begin{array}{l}\text { 水多泥少, 连续冒泡且不停有油花冒出 } \\
\text { 锥高近 } 6 \mathrm{~m}, \text { 火山口半个的泥浆固结有泥裂. }\end{array}$ & 5 & 130 & 61 \\
\hline 阿尔钦沟西南 A & 3.2 & 2.7 & 雉状 & $\begin{array}{l}\text { 未固结的泥浆有三处冒泡, 间歇性冒泡. } \\
\text { 气泡直径约 } 10 \mathrm{~cm} \text {, 水面浮一层油 } \\
\text { 锥高近 } 8 \mathrm{~m} \text {, 火山口一个大气泡后接数个 }\end{array}$ & 10 & 25 & 946 \\
\hline 阿尔钦沟东北 B & 0.75 & 0.75 & 雉状 & $\begin{array}{c}\text { 小气泡, 如此循环, 没有外流沟, 较粘稠, } \\
\text { 有油膜 }\end{array}$ & 25 & 50 & 158 \\
\hline
\end{tabular}

且在地下是连通的. 该泥火山的喷发自晚更新世后 期开始, 直至现在 ${ }^{[16]}$. 阿尔钦沟泥火山是该区可称为 壮观的标准泥火山, 锥形饱满夺人眼宋, 已被铁丝网 围堵以保护并辟为旅游点. 泥火山有关参数见表 1 .

\section{2 气样分析和方法}

泥火山气的组分和碳、氢同位素分析均在中国石 油勘探开研究院廊坊分院, 碳同位素分析采用 Delta plus GC/C/IRMS 同位素质谱仪, 一个样品分析三次, 分析精度达到 $\pm 0.5 \%$, 标准为 V-PDB. 氢同位素分析 应用 MAT253 GC/C/IRMS 同位素质谱仪, 分析精度
达 $\pm 3 \%$, 标准为 V-SMOW. 氦同位素分析在中国科 学院兰州地质研究所气体地球化学重点实验室, 采 用 VG-5400MS 质谱计一次进样在线测量, 测试精度 为 3\% 5\%. 上述分析测试结果见表 2 .

\section{3 泥火山活动日趋衰弱}

1991 年 6 月和 2010 年 8 月, 作者相隔 19 年对研 究区泥火山进行考察并取泥火山气样. 从气压、气量 和泥火山口产状几方面先后两次进行对比, 可见泥 火山活动渐趋衰弱.

1991 年取气样均以漏斗反扣各泥火山口泥浆池 

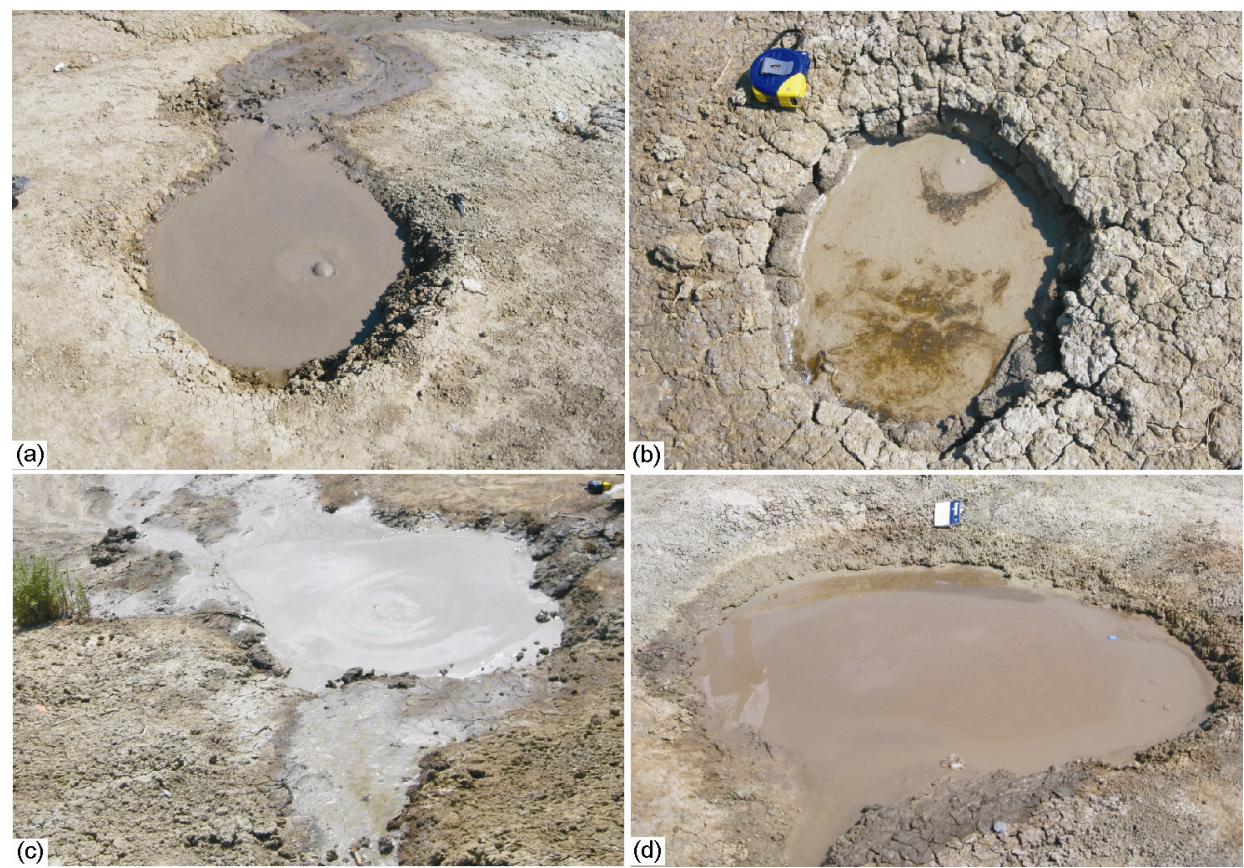

图 4 马东刹拉泥火山口照片

(a) (d)分别对应图 1(b)中自左向右四个泥火山 1 4
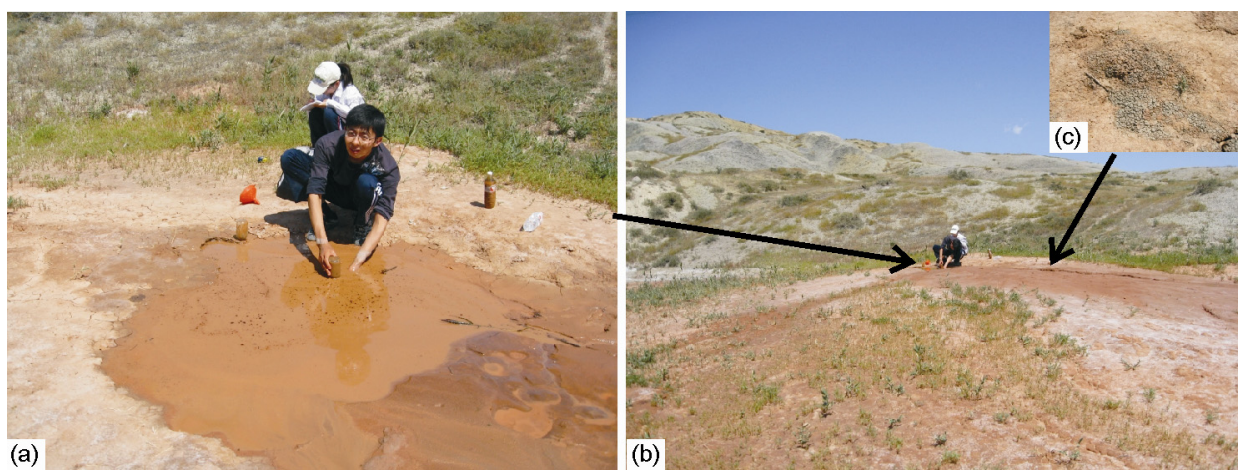

图 5 冒烟沟泥火山喷口及油花 $((\mathbf{a}),(\mathbf{b}))$ 和附近已干涸的泥火山喷口 $(\mathbf{c})$

位置见图 1(b)

出气点, 以乳胶管接漏斗口把气导向盐水塑料桶内 侧置玻璃瓶排水取气法获气样(图 7(b)). 而 2010年除 独山子西北泥火山由于气压力大气量多用 1991 年法 取样外, 其余各泥火山由于气压降低了气量减少了, 故只好把反扣漏斗对准泥火山口泥浆池冒气区，而 漏斗细口伸入盐水瓶进行排水取气(图 3(c), 5(a)). 先 后两次取气样方式改变, 反映了大部分泥火山气压 降低了, 出气量少了.

泥火山口的产状系指是否有泥浆池及其固结程 度, 泥浆池冒或喷气区占池面积大小, 气泡大小及密
度, 气浆喷高, 冒喷气连续性程度及气声响传播距离. 1991 年在离阿尔钦沟泥火山 20 30 m 之外, 就听到 泥火山冒喷出气泡遇空气后破碎发出嘟噜声。阿尔 钦沟西南泥火山口泥浆池面比外缘泥围堤仅低 1 3 $\mathrm{cm}$ ，冒喷气呈圆状处于泥火山口中央，直径 92 95 $\mathrm{cm}$, 冒气柱高达 8 15 cm(图 7(a), (b)), 根据当时取两 个气样单位面积集气平均出气量, 与冒喷气面积计 算，该泥火山年出气量在 $4674 \mathrm{~m}^{3}$ 多. 2010 年该泥火 山口泥浆池比外缘围堤低 $80 \mathrm{~cm}$, 呈陷坑状, 同时部 分围堤呈内陷型塌落, 泥浆池口右边由于无冒气致 


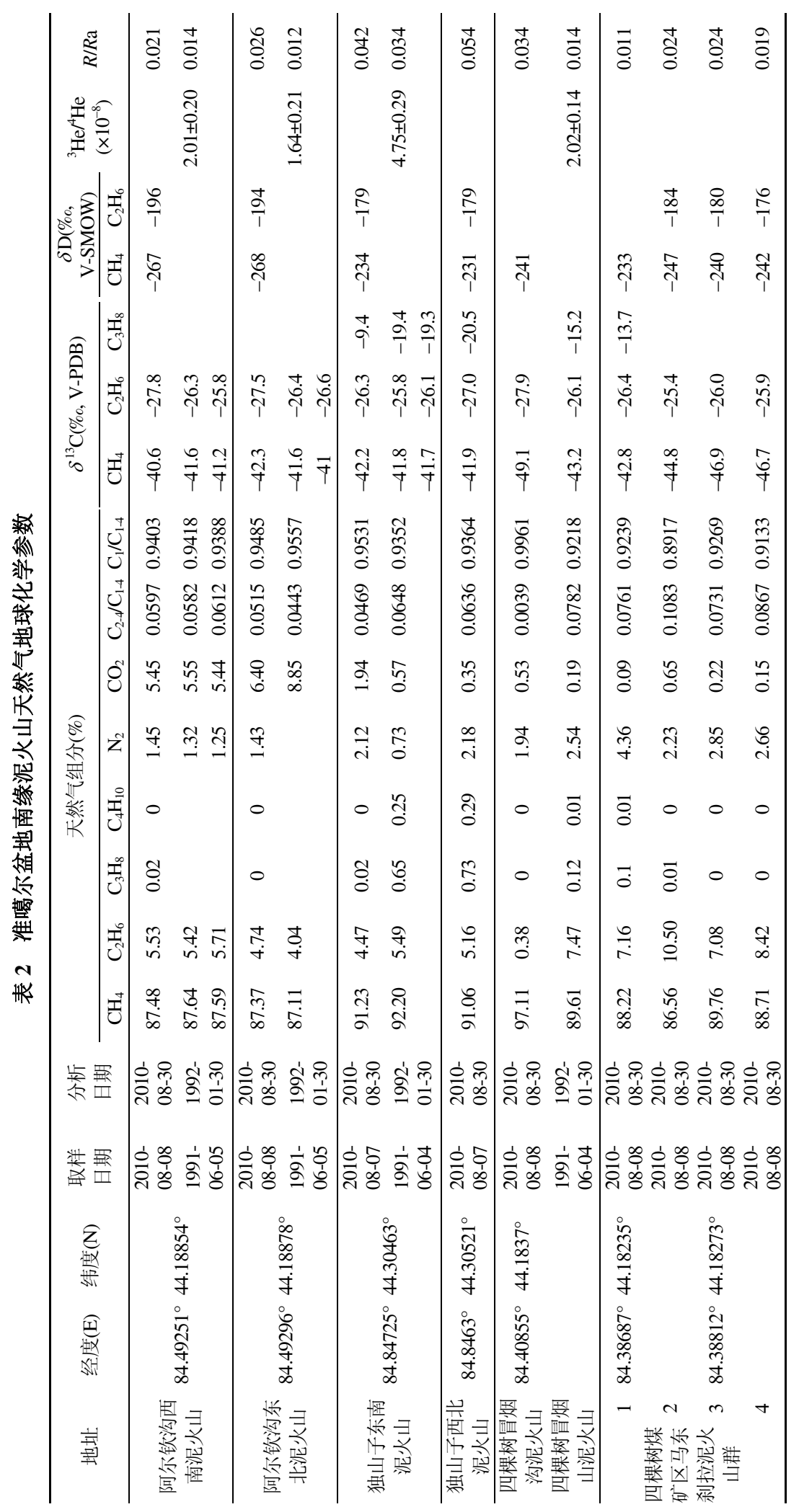




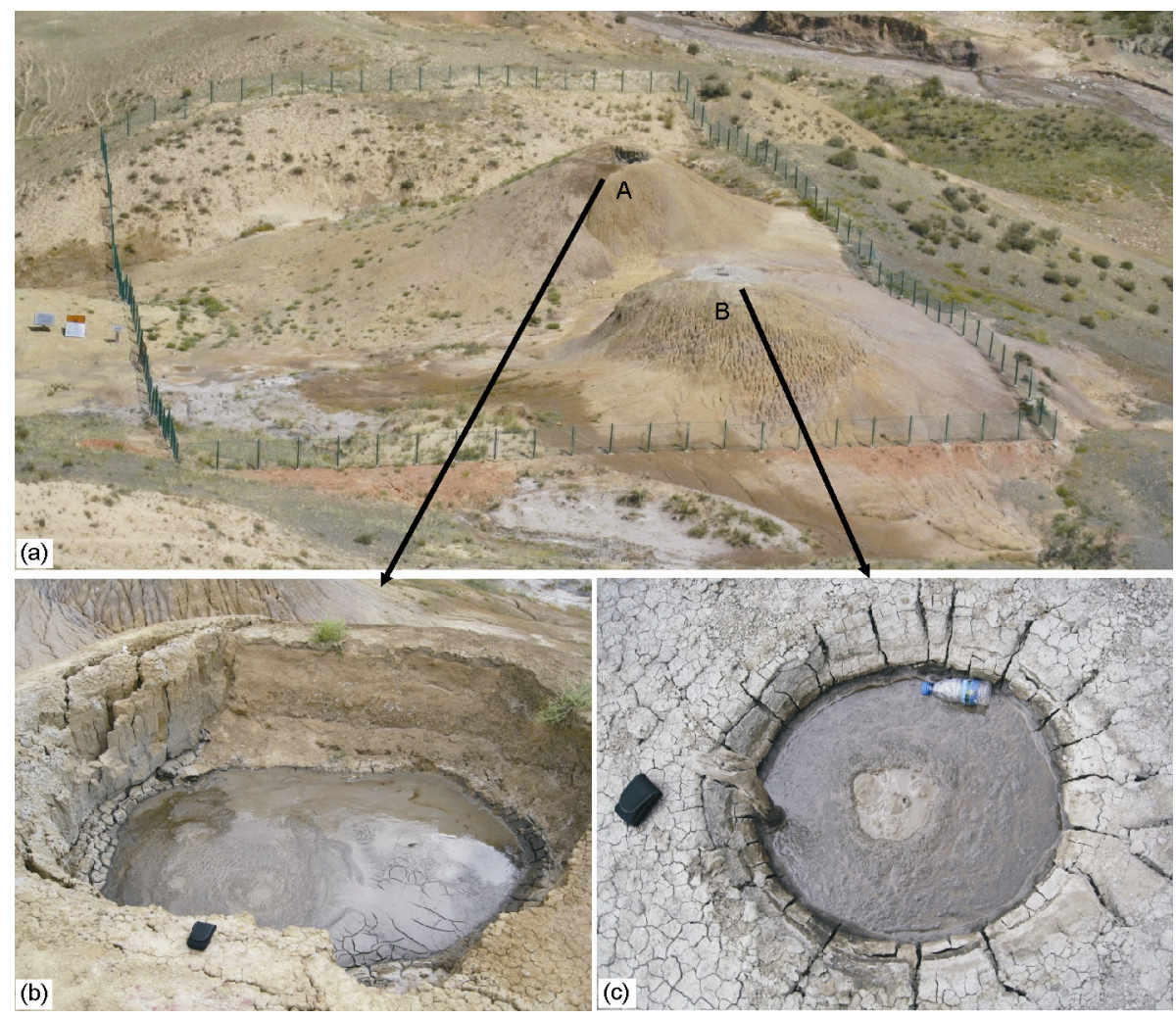

图 6 阿尔钦沟泥火山俯视图(a)和西南泥火山口(b)、东北泥火山口(c) 位置见图 1(c)

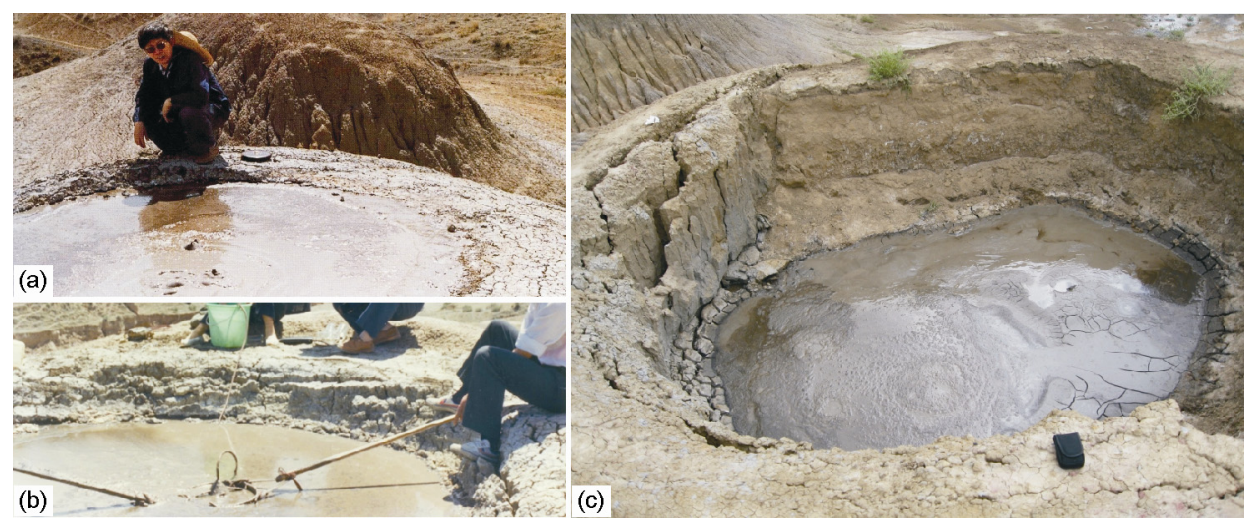

图 7 阿尔钦沟西南泥火山泥浆池口产状

(a) 1991 年; (b) 1991 年取气样; (c) 2010 年

使泥浆固结出现泥裂，冒气区不在泥浆池口中央而 在左边有三处间歇性冒气口(图 7(c)), 根据取气样单 位面积平均出气量与出气面积计算 2010 年该泥火山 出气量为 $946 \mathrm{~m}^{3}$ (表 1), 仅为 1991 年出气量的 $20.2 \%$. 从 1991 年与 2010 年出气量、泥浆池口陷落、泥浆池
干涸等对比，可见该泥火山活动日益衰弱.

2010 年作者一行考察了台湾泥火山, 从乌山顶 泥火山口(图 8(a))与新修女湖泥火山口(图 8(b))产状 分析, 可见此两泥火山正处在活动强度大时期, 而准 噶尔盆地泥火山活动显得逊色. 


\section{4 泥火山天然气组分的地球化学}

表 2 中 16 个气样是相隔近 19 年分两批取的，第 一批气样除阿尔钦沟东北泥火山一个气样的碳同位 素成果发表外 ${ }^{[35]}$,其他成果均未发表. 尽管相隔 19 年先后取气样, 但从表 2 中相同泥火山气样的天然 气主要组分、碳同位素以及氦同位素 $(R / R \mathrm{a})$ 值相近性, 说明了这些泥火山天然气具有固定的同源性或为同 因性.

泥火山天然气的主要组分是烷烃气, 含量从 91.15\%(阿尔钦沟东北泥火山)至 98.59\%(独山子东南 泥火山), 其中甲烷含量最高, 从 $86.56 \%$ (马东刹拉泥 火山群 2 号)至 $97.11 \%$ (冒烟沟泥火山)(图9), 是优质商 业气. 世界上 12 个国家和地区 201 个泥火山气甲烷 含量从 7.4\%(中国台湾 Chung-Lun 泥火山)至 99.54\% (阿塞拜疆 Chukhuroglybozy 泥火山). 但除台湾的外,
绝大部分甲烷含量在 $70 \%$ 以上 ${ }^{[31]}$. 烷烃气湿度 $\left(\mathrm{C}_{2-4} / \mathrm{C}_{1-4}\right)$ 从 0.0039 (四棵树冒烟沟泥火山)至 0.1083 (马 东刹拉泥火山群 2 号), 主要区间为 0.0443 0.0867, 也就是说大部分泥火山天然气属于湿气, 即 $\mathrm{C}_{2-4} / \mathrm{C}_{1-4}>0.05$ (表 2). $\mathrm{N}_{2}$ 的含量从 $0.73 \% \sim 4.36 \%$, 一般 在 $1.25 \%$ 2.85\% 主频率区间(图 9). $\mathrm{CO}_{2}$ 的含量从 0.09\% 8.85\%, 0.20\% 1.0\% 是主频率区间(约 60\%)(图 9). $\mathrm{N}_{2}$ 和 $\mathrm{CO}_{2}$ 含量在常见天然气含量范围之内.

\section{5 泥火山天然气的同位素特征}

\section{1 烷烃气碳同位素}

由表 2 可知, 研究区泥火山气 $\delta{ }^{13} \mathrm{C}_{1}$ 值最重 $-40.6 \%$ o(阿尔钦沟西南泥火山), 最轻的为 $-49.1 \%$ o(冒 烟沟泥火山), 此区间值与世界 201 个泥火山气 $\delta^{13} \mathrm{C}_{1}$

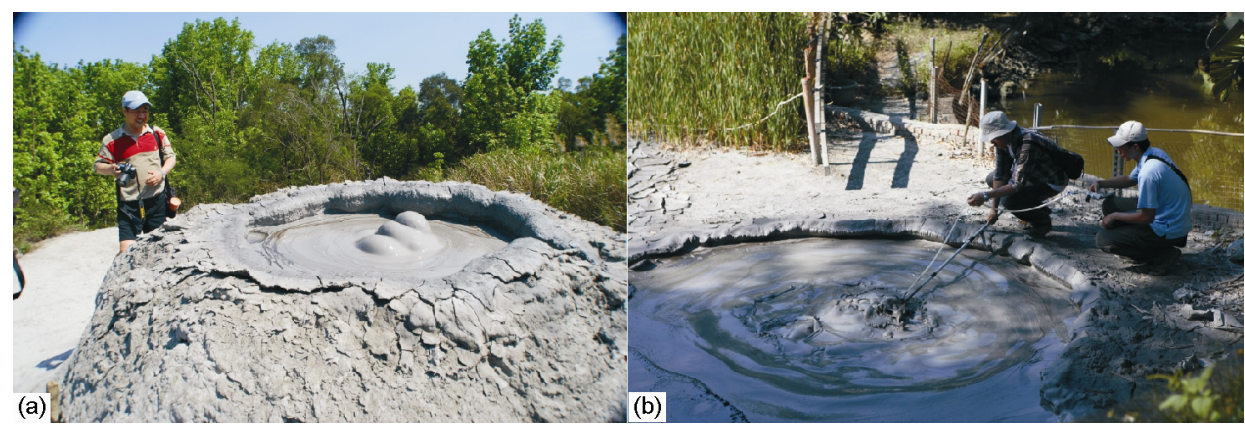

图 8 中国台湾一些泥火山口产状

(a) 乌山顶泥火山; (b) 新修女湖泥火山

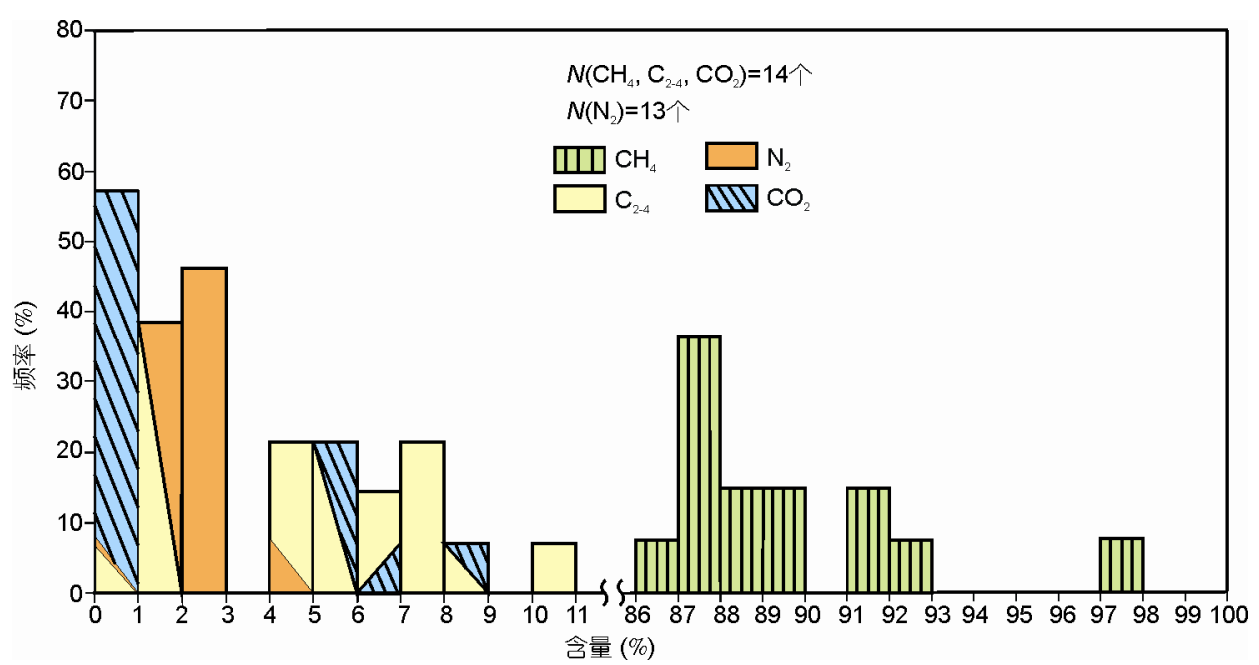

图 9 准噶尔盆地泥火山气组分含量频率图 
频率高峰段一致(图 10) ${ }^{[31]}$. 本区泥火山 $\delta^{13} \mathrm{C}_{1}$ 频率峰 在-40\%o - $42 \%$ o(图 11). $\delta^{13} \mathrm{C}_{2}$ 值最重为 $-25.4 \%$ o(马东 刹拉泥火山群 2 号), 最轻-27.9\% (冒烟沟泥火山), 区 间值仅为 $2.5 \%$ o. $\delta^{13} \mathrm{C}_{3}$ 值最重为 $-9.4 \%$ ( 独山子东南泥 火山), 最轻 $-20.5 \%$ o(独山子西北泥火山).

表 2 中烷烃气碳同位素系列具有 $\delta^{13} \mathrm{C}_{1}<\delta^{13} \mathrm{C}_{2}<$ $\delta^{13} \mathrm{C}_{3}$ 特征, 没有发生倒转, 表明烷烃气是有机成因 的, 未受强的次生改造的原生烷烃气 ${ }^{[36]}$.

阿尔钦沟西南泥火山、阿尔钦沟东北泥火山和独 山子东南泥火山分别在 1991 年和 2010 年先后取得天 然气, $\delta^{13} \mathrm{C}_{1}, \delta^{13} \mathrm{C}_{2}$ 和 $\delta{ }^{13} \mathrm{C}_{3}$ 分析值十分接近(表 2), 说 明这些泥火山天然气具同源性或同因性.

\section{2 烷烃气氢同位素}

由表 2 可知, 泥火山烷烃气 $\delta \mathrm{D}_{1}$ 最重为 $-231 \%$ 。

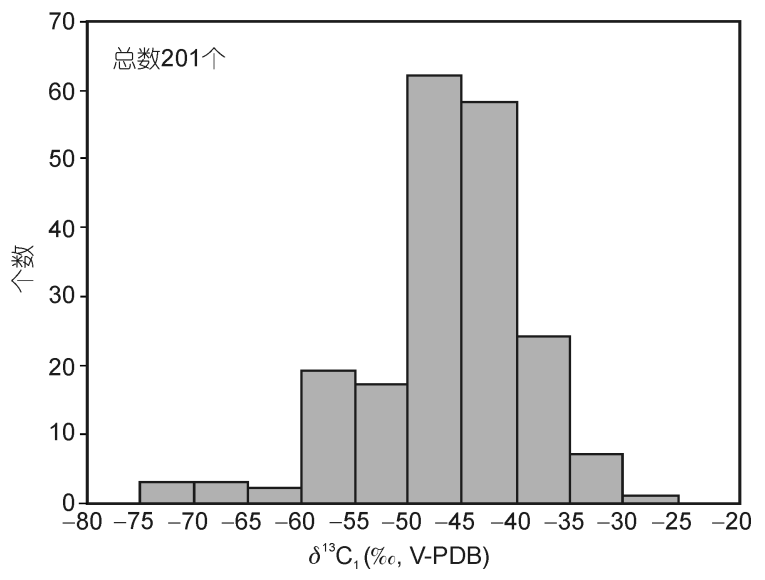

图 10 世界 201 个泥火山气 $\delta^{13} \mathrm{C}_{1}$ 频率图 $^{[31]}$

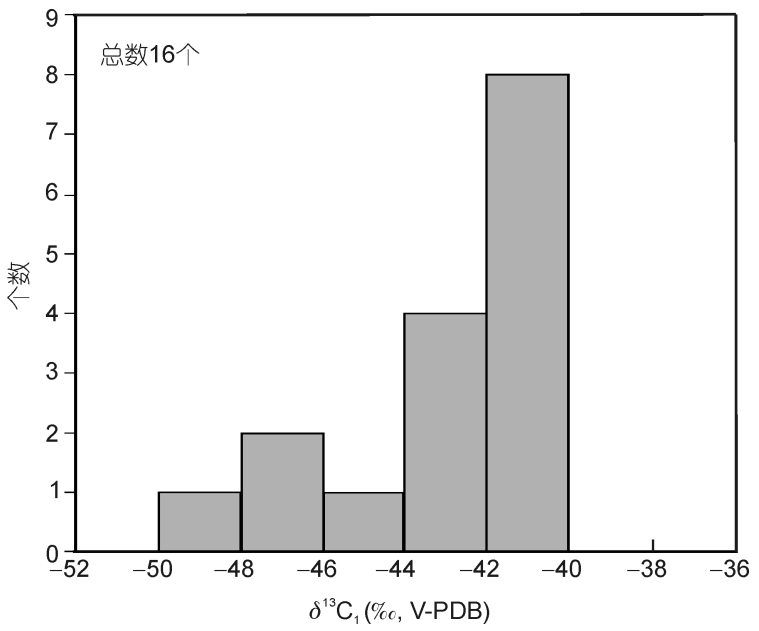

图 11 准噶尔盆地南缘泥火山气 $\delta^{13} \mathrm{C}_{1}$ 频率图
(独山子西北泥火山), 最轻的为 $-268 \%$ (阿尔钦沟东 北泥火山), 比阿塞拜疆、格鲁吉亚、意大利、新西兰、 巴布亚、罗马尼亚和土库曼斯坦泥火山气的 $\delta \mathrm{D}_{1}$ 值普遍 要轻 ${ }^{[31]}$, 同时比我国台湾泥火山气 $\delta \mathrm{D}_{1}$ 多轻 ${ }^{[31]}$ (图 12). 泥火山气 $\delta \mathrm{D}_{2}$ 最重为 $-176 \%$ (马东刹拉泥火山群 4 号), 最轻的为 $-196 \%$ (阿尔钦沟西南泥火山). 世界泥火山 气的 $\delta \mathrm{D}_{2}$ 研究未见报道.

\section{3 氦同位素}

氦有 5 个同位素 $\left({ }^{3} \mathrm{He},{ }^{4} \mathrm{He},{ }^{5} \mathrm{He},{ }^{6} \mathrm{He},{ }^{8} \mathrm{He}\right),{ }^{3} \mathrm{He}$ 和 ${ }^{4} \mathrm{He}$ 是稳定同位素, 其余 3 个为不稳定同位素. ${ }^{3} \mathrm{He}$ 和 ${ }^{4} \mathrm{He}$ 在成因上有显著的差异, ${ }^{3} \mathrm{He}$ 是与地幔有关的原 始成因氦; ${ }^{4} \mathrm{He}$ 是与地壳中放射性物质铀、针 $\alpha$ 衰变有 关. 在地球不同圈层中 ${ }^{3} \mathrm{He} /{ }^{4} \mathrm{He}$ 比值和 $R / R \mathrm{a}(R$ 为样品 中 ${ }^{3} \mathrm{He} /{ }^{4} \mathrm{He}, R \mathrm{a}$ 为大气中 $\left.{ }^{3} \mathrm{He} /{ }^{4} \mathrm{He}\right)$ 差异明显. 壳源氦的 ${ }^{3} \mathrm{He} /{ }^{4} \mathrm{He}$ 值随岩石类型不同有很大变化, 其范围值从 $10^{-7} \sim 10^{-9}$, 典型值在 $10^{-8[37 \sim 38]}$. 戴金星等 ${ }^{[39]}$ 根据鄂尔 多斯盆地 46 个气样 ${ }^{3} \mathrm{He} /{ }^{4} \mathrm{He}$ 值为 $3.18 \times 10^{-8} \sim 1.20 \times 10^{-7}$, 平均值为 $4.36 \times 10^{-8}, R / R \mathrm{a}$ 为 $0.022 \sim 0.085$, 认为均是 壳源氦. 前苏联大陆区天然气中多数地壳气的 ${ }^{3} \mathrm{He} /{ }^{4} \mathrm{He}$ 在 $7 \times 10^{-9} \sim 2 \times 10^{-7}(R / R \mathrm{a}=0.005 \sim 0.1)$. 一般认为 地壳氦的 $R / R \mathrm{a}$ 值为 $0.01 \sim 0.1^{[40 \sim 41]}$. 上地壳氦的 ${ }^{3} \mathrm{He} /{ }^{4} \mathrm{He}$ 正常值为 $1.2 \times 10^{-5}$, 或在 $(1.1 \sim 1.4) \times 10^{-5[38,40]}$.

由表 2 可知, 研究区泥火山气中 ${ }^{3} \mathrm{He} /{ }^{4} \mathrm{He}$ 值在 $10^{-8}, R / R \mathrm{a}$ 在 0.011 (马东刹拉泥火山群 1 号) 0.054(独

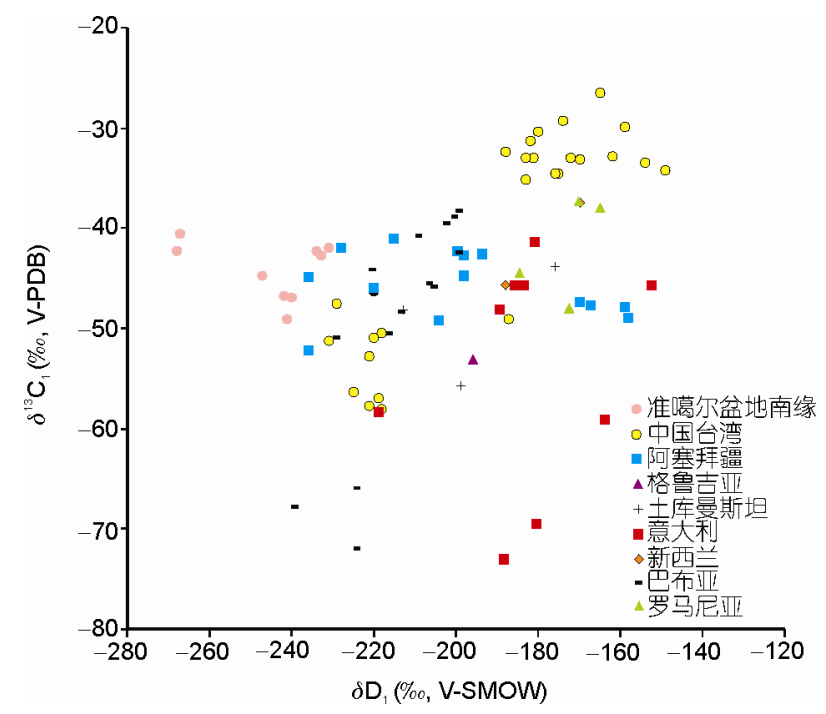

图 12 不同地区泥火山气 $\delta \mathrm{D}_{1}-\delta^{13} \mathrm{C}_{1}$ 对比 准噶尔盆地南缘数据见表 2, 其余数据见文献[31] 
山子西北泥火山), 在上述壳源氦 ${ }^{3} \mathrm{He} /{ }^{4} \mathrm{He}$ 和 $R / R \mathrm{a}$ 数 值域内, 故也应属壳源氦. 由表 2 可见, 独山子地区 两个泥火山气的 $R / R \mathrm{a}$ 值, 1991 年和 2010 年两次先后 分析, 在研究区中是最高的, 即为 0.034 和 0.054 . 此 值与独山子油气田独 85 井 575 597 $\mathrm{m} \mathrm{N}_{2}$ 地层中天然 气 $R / R \mathrm{a}$ 值 0.034 一致, 说明独山子地区泥火山天然气 来源于深部地层.

\section{6 泥火山天然气的成因类型和气源}

\section{1 成因类型}

研究区泥火山气的主要组分是烷烃气, 其占相 关气样组分 $91.15 \%$ (阿尔钦沟东北泥火山) 97.49\% (冒烟沟泥火山), 故着重探讨烷烃气的成因类型.

烷烃气随分子中碳数的渐增碳同位素逐渐变重, 即 $\delta^{13} \mathrm{C}_{1}<\delta{ }^{13} \mathrm{C}_{2}<\delta{ }^{13} \mathrm{C}_{3}$ 是有机成因烷烃气的特点 ${ }^{[36,42]}$. 由表 2 泥火山烷烃气具有 $\delta^{13} \mathrm{C}_{1}<\delta{ }^{13} \mathrm{C}_{2}<\delta^{13} \mathrm{C}_{3}$ 特征, 故肯定这些烷烃气是有机成因的. 众所周知根据烃 源岩生气的成熟度, 有机成因气一般以 $\delta^{13} \mathrm{C}_{1}$ 值 $-55 \% 0^{[43 \sim 45]}$ 为界, 轻于 $-55 \%$ 是生物成因气, 重于 $-55 \%$ o 为热成因气. 根据表 2 中 $\delta^{13} \mathrm{C}_{1}$ 值比 $-55 \%$ 重的 多, 故应归热成因气. 热成因气又依据成气源岩是腐 殖型或腐泥型又分为煤成气和油型气, 因此泥火山 的烷烃气应为此两种成因气之一。

根据相同或相近成熟度源岩形成的煤成气甲烷 及其同系物的 $\delta^{13} \mathrm{C}$ 值, 比油型气对应组分的 ${ }^{13} \mathrm{C}$ 值 重的特征 ${ }^{[42]}$; 乙烷碳同位素组成受源岩成熟度的影 响比甲烷同位素小, 即乙烷碳同位素组成对于源岩 母质的碳同位素组成, 比甲烷碳同位素组成有较好
的反映 ${ }^{[46]}$, 因此可利用乙烷碳同位素值来鉴别煤成 气和油型气. 1988 年张士亚等 ${ }^{[46]}$ 指出: 煤成气 $\delta^{13} \mathrm{C}_{2}>$ $-29 \%$ ，油型气 $\delta^{13} \mathrm{C}_{2}<-29 \%$; 戴金星等 ${ }^{[42]}$ 指出煤成 气 $\delta^{13} \mathrm{C}_{2}>-25.1 \%$, 油型气 $\delta^{13} \mathrm{C}_{2}<-28.8 \%$; 1994 年王世 谦 ${ }^{[47]}$ 对四川盆地从震旦系至侏罗系煤成气和油型气 的烷烃气碳同位素作系统研究对比后指出: 煤成气 $\delta^{13} \mathrm{C}_{2}>-29 \% ; 2005$ 年戴金星等 ${ }^{[48]}$ 在综合研究全国大 量煤成气和油型气的 $\delta^{13} \mathrm{C}_{2}$ 值后, 认为煤成气 $\delta^{13} \mathrm{C}_{2}>$ $-27.5 \%$ o, 油型气 $\delta^{13} \mathrm{C}_{2}<-29 \%$; 2009 年 Dai 等 ${ }^{\left[{ }^{[9]}\right.}$ 根据 四川盆地须家河组大量烷烃气碳同位素组成研究得出: 煤成气 $\delta^{13} \mathrm{C}_{2}>-28 \%$ 。综合以上学者鉴定煤成气 $\delta^{13} \mathrm{C}_{2}$ 有四个值: > $-29 \%$, > $-28.0 \%$ o, >-27.5\%o和> $-25.1 \%$, 后 三个值在研究者检验中国、德国、俄罗斯、加拿大和 澳大利亚煤成气都符合. 由于煤成气 $\delta^{13} \mathrm{C}_{2}>-28 \%$, 实际上包括>- $27.5 \%$ 和 $>-25.1 \%$ 在内, 故三个值可以 $\delta^{13} \mathrm{C}_{2}>-28 \%$ o 来概括. 因此, 实际上作为鉴别标志值 只剩下 $\delta^{13} \mathrm{C}_{2}>-29 \%$ 和 $\delta{ }^{13} \mathrm{C}_{2}>-28 \%$ 两个值. 此两值 可否合并或其中何值有代表性. 为此对我国具有 $\delta^{13} \mathrm{C}_{1}<\delta^{13} \mathrm{C}_{2}<\delta{ }^{13} \mathrm{C}_{3}<\delta{ }^{13} \mathrm{C}_{4}$ 原生型特征的油型气, $\delta^{13} \mathrm{C}_{2}$ 最重值大于 $-29 \%$ 井作了挑选(表 3). 由表 3 可 知, 我国油型气 $\delta^{13} \mathrm{C}_{2}$ 值在苏北盆地永 7 井和真 98 井 可重达-28.4\%o, 其他气(油)田也见到不少 $\delta^{13} \mathrm{C}_{2}$ 值 -28.5\% - 28.9\%。. 美国 Texas 州 Barnett 页岩气是油 型气, 因为 50 个有效气样中 49 个 $\delta^{13} \mathrm{C}_{2}$ 值-29.4\% $-39.9 \%$, 仅有一个 (Group 2B 之 $\mathrm{Y}$ ) $\delta^{13} \mathrm{C}_{2}$ 值为 $-28.1 \% o^{[50]}$. 据以上分析对比, 以 $\delta^{13} \mathrm{C}_{2}>-28 \%$ o作为煤 成气鉴别标志值较合适. 由于表 2 中泥火山天然气的 $\delta^{13} \mathrm{C}_{2}$ 值均大于 $-28 \%$, 所以准噶尔盆地南缘泥火山 中烷烃气都是煤成气.

表 3 中国油型气 $\delta^{13} \mathrm{C}_{2}$ 最重值

\begin{tabular}{|c|c|c|c|c|c|c|c|c|c|c|c|c|c|}
\hline \multirow{2}{*}{ 气(油)田 } & \multirow{2}{*}{ 井号 } & \multirow{2}{*}{ 层位 } & \multirow{2}{*}{ 井深(m) } & \multicolumn{6}{|c|}{ 天然气组分 $(\%)$} & \multicolumn{4}{|c|}{$\delta^{13} \mathrm{C}(\%$, , PDB $)$} \\
\hline & & & & $\mathrm{CH}_{4}$ & $\mathrm{C}_{2} \mathrm{H}_{6}$ & $\mathrm{C}_{3} \mathrm{H}_{8}$ & $\mathrm{C}_{4} \mathrm{H}_{10}$ & $\mathrm{~N}_{2}$ & $\mathrm{CO}_{2}$ & $\mathrm{CH}_{4}$ & $\mathrm{C}_{2} \mathrm{H}_{6}$ & $\mathrm{C}_{3} \mathrm{H}_{8}$ & $\mathrm{C}_{4} \mathrm{H}_{10}$ \\
\hline \multirow{4}{*}{ 卧龙河 } & 卧 2 & $\mathrm{~T}_{1} j^{5}$ & $1633 \sim 1673$ & 92.53 & 0.83 & 0.21 & 0.07 & 0.58 & 0.74 & -32.8 & -28.7 & -23.5 & \\
\hline & 卧 3 & $\mathrm{~T}_{1} j^{5}$ & 1288 & 93.11 & 0.58 & 0.21 & 0.14 & 0.74 & 0.34 & -32.7 & -28.9 & -24.3 & \\
\hline & 卧 25 & $\mathrm{~T}_{1} j^{5}$ & $1649.52 \sim 1690$ & 92.27 & 0.87 & 0.23 & 0.07 & 0.55 & 0.71 & -33.0 & -28.9 & -24.2 & \\
\hline & 卧 13 & $\mathrm{~T}_{1} j^{5}$ & 1570 & 92.40 & 0.80 & 0.20 & 0.16 & 0.78 & 0.46 & -33.1 & -28.7 & -25.9 & -24.2 \\
\hline 普光 & 普光 2 & $\mathrm{~T}_{1} f^{3}$ & $4776.8 \sim 4826$ & 76.69 & 0.19 & 0 & 0 & 0.40 & & -30.9 & -28.5 & & \\
\hline 菄园 & 崽 $1235-1$ & $\mathrm{E} s_{1}$ & $1756.6 \sim 1770$ & 93.72 & 1.52 & 1.15 & 0.54 & 2.41 & 0.53 & -47.8 & -28.9 & -28.3 & \\
\hline 安茨 & 安 69-11 & $\mathrm{Es}_{3}$ & $2875.2 \sim 2838.4$ & 90.31 & 6.49 & 2.32 & 0.3 & 0.36 & 0.52 & -46.3 & -28.8 & -27.9 & -27.4 \\
\hline 别古庄 & 京 257 & $\mathrm{E} s_{4}$ & $1523 \sim 1591$ & 97.51 & 1.17 & 0.33 & 0.15 & 0.32 & 0.44 & -45.3 & -28.5 & -24.3 & -23.8 \\
\hline 永安 & 永 7 & $\mathrm{E}_{1} d$ & $2995.4 \sim 3029.4$ & 84.05 & 8.04 & 2.93 & 1.65 & 1.36 & 1.22 & -44.8 & -28.4 & -26.1 & \\
\hline 真武 & 真 98 & $\mathrm{E}_{1} d$ & $2569.6 \sim 2713.0$ & 84.64 & 8.52 & 3.75 & 1.44 & 0.77 & 0 & -44.5 & -28.4 & -27.3 & -27.3 \\
\hline 尔斯库勒 & 跃 11-6 & $\mathrm{E}_{3}{ }^{1}$ & $3221.0 \sim 3414.4$ & 76.94 & 10.92 & 5.49 & 2.35 & 2.55 & 0.71 & -42.0 & -28.7 & -26.3 & -26.2 \\
\hline
\end{tabular}




\section{2 气源}

准噶尔盆地目前发现有工业性煤成气的气源岩 有两套: (1) 石炭系下统滴水泉组和上统巴塔玛依内 山组, 均是煤系源岩, 源岩以腐殖型为主, 在盆地中 部已发现千亿立方米以上克拉美丽大气田等, 气为 干气 ${ }^{[1 \sim 53]}, \mathrm{C}_{1} / \mathrm{C}_{1-4}$ 值 0.960 0.975, 天然气地球化学特 征见表 4. (2) 下中侏罗统八道湾组和西山窑组, 均为 煤系源岩, 有机质类型以利于生气的 II ${ }_{2}$-III型为主. 烃源岩主要分布在盆地的中部与南部, 从盆地北部 向南缘烃源岩埋深加大, 有机质成熟度逐渐增大, 盆 地北部 $R_{\mathrm{o}}$ 为 $0.58 \% \sim 0.73 \%$, 盆地腹部至南缘 $R_{\mathrm{o}}$ 值为 $0.83 \% \sim 2.5 \%{ }^{[53]}$. 气以湿气为主, $\mathrm{C}_{1} / \mathrm{C}_{1-4}$ 值为 $0.818 \sim$ 0.941 , 仅有滴西 10 井 $\left(\mathrm{K}_{1} h\right)$ 等 4 口井 $\mathrm{C}_{1} / \mathrm{C}_{1-4}$ 值为 0.950 0.957, 即使 $\mathrm{C}_{1} / \mathrm{C}_{1-4}$ 最大值 0.957 也小于石炭系 煤成气最小值 0.960 . 因此, 石炭系源岩形成的煤成 气比下中侏罗统形成的煤成气干.

由表 4 可知, 石炭系源岩形成的煤成气 $\delta^{13} \mathrm{C}_{1}$ 值 为 $-29.5 \%$ - 30.5\% , 而下中侏罗统源岩形成的煤成 气 $\delta^{13} \mathrm{C}_{1}$ 值从-32.6\% (玛纳 1) 至- $40.7 \%$ o(独 62a), 即石 炭系源岩形成煤成气比下中侏罗统源岩形成煤成气 的 $\delta^{13} \mathrm{C}_{1}$ 值重. 从滴西 10 井石炭系煤成气 $\delta^{13} \mathrm{C}_{1}$ 值比 下中侏罗统源岩形成聚集在下白严统 $\left(\mathrm{K}_{1} h\right)$ 重约 4\% 5\%。 . 导致两者轻重不同, 是因为石炭系源岩成
熟度高, 故其煤成气 $\delta^{13} \mathrm{C}_{1}$ 值重, 而下中侏罗统源岩 成熟度相对低, 故其煤成气 $\delta^{13} \mathrm{C}_{1}$ 值轻.

可利用石炭系源岩形成的煤成气 $\mathrm{C}_{1} / \mathrm{C}_{1-4}$ 大和 $\delta^{13} \mathrm{C}_{1}$ 值重, 而下中侏罗统源岩形成的煤成气 $\mathrm{C}_{1} / \mathrm{C}_{1-4}$ 小和 $\delta^{13} \mathrm{C}_{1}$ 值轻这两个指标, 来判别两种源岩形成的 煤成气. 由表 2 可知, 准噶尔盆地南缘泥火山天然气 $\mathrm{C}_{1} / \mathrm{C}_{1-4}$ 除四棵树冒烟沟泥火山的为 0.996 异常大外, 其他的均小于该盆地下中侏罗统源岩形成的最大值 0.957. 泥火山的 $\delta^{13} \mathrm{C}_{1}$ 值-40.0\% - 49.1\%o, 均轻于石 炭系煤成气的 $\delta^{13} \mathrm{C}_{1}$ 值-29.5\%o - $30.5 \%$ ，最重值 $-40.0 \%$ o(表 2, 阿尔钦沟西南泥火山)与下中侏罗统源 岩形成的煤成气 $\delta^{13} \mathrm{C}_{1}$ 值 $-40.7 \%$ (表 4, 独 62a) 基本接 近，但绝大部分 $\delta^{13} \mathrm{C}_{1}$ 值轻于 $-41 \%$ 。 基于泥火山天然 气 $\mathrm{C}_{1} / \mathrm{C}_{1-4}$ 和 $\delta^{13} \mathrm{C}_{1}$ 值两指标具有与该盆地下中侏罗统 源岩形成煤成气的相同数值域的特征，所以可以得 出准噶尔南缘泥火山的烷烃气的气源, 是基本来自 下中侏罗统源岩形成的煤成气．在此“基本来自”的 意思是由于：一是 $\mathrm{C}_{1} / \mathrm{C}_{1-4}$ 值冒烟沟泥火山高达 0.996 , 比石炭系煤成气的高得多，是异常值; 二是因为冒烟 沟泥火山 $\delta^{13} \mathrm{C}_{1}$ 值为 $-49.1 \%$ ，比其他泥火山的 $\delta^{13} \mathrm{C}_{1}$ 值轻得多，也是个异常值. 同一泥火山的烷烃气出现 此两异常，可能显示受到其他因素影响.上述提到在 冒烟沟泥火山有一片小的芦苇地(图 5(b)), 是否由芦 苇形成几乎以甲烷为主的具有 $\delta^{13} \mathrm{C}_{1}<-55 \%$ 轻的生物

表 4 准噶尔盆地石炭系煤成气与下中侏罗统源岩形成的煤成气 $\mathrm{C}_{1} / \mathrm{C}_{1-4}$ 和 $\delta^{13} \mathrm{C}$ 对比表

\begin{tabular}{|c|c|c|c|c|c|c|c|c|c|c|c|c|}
\hline \multirow{2}{*}{ 井号 } & \multirow{2}{*}{ 层位 } & \multirow{2}{*}{ 井深(m) } & \multicolumn{5}{|c|}{ 天然气主要组分 $(\%)$} & \multicolumn{4}{|c|}{$\delta^{13} \mathrm{C}(\% o, \mathrm{PDB})$} & \multirow{2}{*}{ 文献 } \\
\hline & & & $\mathrm{CH}_{4}$ & $\mathrm{C}_{2} \mathrm{H}_{6}$ & $\mathrm{C}_{3} \mathrm{H}_{8}$ & $\mathrm{C}_{4} \mathrm{H}_{10}$ & $\mathrm{C}_{1} / \mathrm{C}_{1-4}$ & $\mathrm{CH}_{4}$ & $\mathrm{C}_{2} \mathrm{H}_{6}$ & $\mathrm{C}_{3} \mathrm{H}_{8}$ & $\mathrm{C}_{4} \mathrm{H}_{10}$ & \\
\hline \multirow{3}{*}{ 滴西 10} & C & 3070 & 91.67 & 2.54 & 0.76 & 0.44 & 0.960 & -30.1 & -27.7 & -24.5 & & \multirow{8}{*}{ [53] } \\
\hline & $c$ & 3024 & 90.97 & 2.48 & 0.73 & 0.41 & 0.961 & -29.5 & -26.6 & -24.6 & -24.5 & \\
\hline & $\mathrm{K}_{1} h$ & 1397 & 84.04 & 3.38 & 0.19 & 0.17 & 0.957 & -34.4 & -25.1 & & & \\
\hline 滴西 8 & $\mathrm{~J}_{1} s$ & 2253 & 87.27 & 4.58 & 1.85 & 1.09 & 0.920 & -39.0 & -27.7 & -25.3 & -26.3 & \\
\hline 滴西 9 & $\mathrm{~K}_{1}$ & 2110 & 89.85 & 3.27 & 1.31 & 1.00 & 0.941 & -33.7 & -27.2 & -24.6 & -26.3 & \\
\hline \multirow{2}{*}{ 彩 31} & $\mathrm{C}_{2}$ & 3260 & 92.45 & 1.95 & 0.42 & & 0.975 & -29.5 & -26.7 & -25.6 & -24.4 & \\
\hline & $\mathbf{J}_{1} b$ & 2910 & & & & & & -38.0 & -27.9 & -24.8 & -23.0 & \\
\hline 彩 25 & $\mathrm{C}_{2}$ & 3028 & 94.37 & 2.13 & 0.46 & & 0.973 & -30.0 & -24.2 & -22.6 & -22.3 & \\
\hline 彩参 1 & $\mathrm{C}_{2}$ & $2862 \sim 2890$ & 77.85 & 2.12 & 0.14 & & 0.971 & -30.5 & -19.9 & & & \multirow{3}{*}{$\begin{array}{l}\text { 本文 } \\
\text { [53] }\end{array}$} \\
\hline 独 1 & $\mathrm{~N}_{1} t$ & 868 & 82.53 & 8.86 & 3.27 & 0.00 & 0.871 & -37.5 & -27.1 & -24.4 & -24.4 & \\
\hline 独 62a & $\mathrm{E}_{3}$ & $1285 \sim 1926$ & 80.02 & 4.29 & 2.57 & 1.38 & 0.906 & -40.7 & -26.5 & -24.6 & -23.4 & \\
\hline 独 85 & $\mathrm{~N}_{2}$ & $575 \sim 597$ & 80.65 & 9.95 & 5.80 & 2.17 & 0.818 & -40.4 & -27.5 & -22.7 & -21.0 & 本文 \\
\hline 霍 3 & $\mathrm{~N}_{1}-\mathrm{E}_{3}$ & $541 \sim 1135$ & 84.92 & 5.07 & 0.93 & 0.34 & 0.930 & -36.5 & -22.5 & -22.3 & -21.6 & \\
\hline \multirow{2}{*}{ 霍 10} & \multirow{2}{*}{$\mathrm{E}_{1-2} z$} & 3064 & 90.13 & 6.39 & 1.41 & 0.70 & 0.913 & -33.6 & -23.0 & -22.1 & -22.0 & \multirow{2}{*}{ [53] } \\
\hline & & 3159 & 83.85 & 9.91 & 3.14 & 1.47 & 0.852 & -34.4 & -24.1 & -24.0 & -23.9 & \\
\hline 呼 2 & $\mathrm{E}_{1-2} z$ & $3594 \sim 3597$ & 93.58 & 3.88 & 0.66 & 0.34 & 0.950 & -37.8 & -23.0 & -21.3 & -21.0 & 本文 \\
\hline 玛纳 1 & $\mathrm{E}_{1-2} z$ & $2557 \sim 2561$ & 93.01 & 3.63 & 0.45 & 0.16 & 0.956 & -32.6 & -25.1 & -21.1 & & 刘得光通 \\
\hline 玛纳 2 & $\mathrm{E}_{1-2} z$ & 2520 2524 & 87.26 & 3.16 & 0.52 & 0.20 & 0.957 & -32.8 & -24.7 & -24.1 & -23.3 & 讯资料 \\
\hline
\end{tabular}


气, 与从下中侏罗统源岩形成的煤成气的甲烷相混, 致使 $\delta^{13} \mathrm{C}_{1}$ 值变轻, $\mathrm{C}_{1} / \mathrm{C}_{1-4}$ 值变大.

\section{7 结论}

（1）通过时隔 19 年两次对准噶尔盆地南缘泥火 山的考察, 从气压减小、出气量减少、泥浆池口陷 落和泥浆池干涸等变化, 可见该区泥火山活动渐趋 衰弱.

（2）泥火山天然气具有相似的地球化学特征, 表 明其具有同源性或同因性. 泥火山天然气主要组分 是烷烃气, 含量为 $91.15 \% \sim 97.49 \%$, 其中甲烷含量最
高, 是优质商业气; 天然气 $\delta^{13} \mathrm{C}_{1}$ 值为 $-49.1 \%$ $-40.6 \%$, 与世界范围内泥火山气 $\delta^{13} \mathrm{C}_{1}$ 频率高峰段一 致, 且烷烃气碳同位素系列具有 $\delta^{13} \mathrm{C}_{1}<\delta{ }^{13} \mathrm{C}_{2}<\delta{ }^{13} \mathrm{C}_{3}$ 特征, 是典型热成因气; 研究区泥火山气具有较低的 ${ }^{3} \mathrm{He} /{ }^{4} \mathrm{He}$ 值, $R / R \mathrm{a}$ 为 $0.011 \sim 0.054$, 属典型壳源氦.

(3) 泥火山天然气的 $\delta^{13} \mathrm{C}_{2}$ 值均大于 $-28 \%$ ，是 典型煤成气, 且 $\mathrm{C}_{1} / \mathrm{C}_{1-4}$ 和 $\delta^{13} \mathrm{C}_{1}$ 值两指标与该盆地下 中侏罗统源岩形成煤成气的特征一致, 因此, 准噶 尔盆地南缘泥火山烷烃气的气源主要是下中侏罗统 煤系源岩.

(4) 泥火山是勘探发现油气田的重要标志，也是 表征地下断裂的存在.

致谢新疆油田公司勘探开发研究院范光华、袁文贤高级工程师指导泥火山踏勘与取样, 参加第一、二次取样的还 有陈世加教授、宋岩教授级高级工程师、洪峰、胡国艺高级工程师和廖凤蓉博士，审稿专家提出宝贵意见，在 此一并致谢.

\section{参考文献}

1 刘嘉麒. 大地“沸腾”——泥火山. 大自然探索, 2003, 22: 8-9

2 Dimitrov L I. Mud volcanoes-The most important pathway for degassing deeply buried sediments. Earth-Sci Rev, 2002, 59: 49-76

3 Kopf A J. Significance of mud volcanism. Rev Geophys, 2002, 40: 1005, doi: 1010.1029/2000RG000093

4 Etiope G, Caracausi A, Favara R, et al. Methane emission from the mud volcanoes of Sicily (Italy). Geophys Res Lett, 2002, 29: 1215, doi: 1210.1029/2001GL014340

5 Shakirov R, Obzhirov A, Suess E, et al. Mud volcanoes and gas vents in the Okhotsk Sea area. Geo-Mar Lett, 2004, 24: 140-149

6 Planke S, Svensen H, Hovland M, et al. Mud and fluid migration in active mud volcanoes in Azerbaijan. Geo-Mar Lett, 2003, 23: 258-268

7 Davies R J, Mathias S A, Swarbrick R E, et al. Probabilistic longevity estimate for the LUSI mud volcano, East Java. J Geol Soc, 2011, 168: 517-523

8 Mazzini A, Svensen H, Akhmanov G G, et al. Triggering and dynamic evolution of the LUSI mud volcano, Indonesia. Earth Planet Sci Lett, 2007, 261: 375-388

9 钟华邦. 我国的泥火山简述. 地质科技情报, 1986, 5: 58

10 陈秉范. 四川盆地式泥火山的发现. 地质论评, 1946, 11: 65-70

11 胡东生, 张华京. 青藏高原可可西里地区玛章错钦湖畔苟纠麦尔沟的泥火山机理雉议. 干旱区地理, 1998, 21: 13-18

12 Yang T F, Yeh G H, Fu C C, et al. Composition and exhalation flux of gases from mud volcanoes in Taiwan. Environ Geol, 2004, 46: 1003-1011

13 朱婷婷, 陆现彩, 祝幼华, 等. 台湾西南部乌山顶泥火山的成因机制初探. 岩石矿物学杂志, 2009, 28: 465-472

14 Sun C H, Chang S C, Kuo C L, et al. Origins of Taiwan's mud volcanoes: Evidence from geochemistry. J Asian Earth Sci, 2010, 37 : 105-116

15 王道. 新疆北天山地区泥火山与地震. 内陆地震, 2000, 14: 350-353

16 彭希龄. 谈谈新疆的泥火山. 西部油气勘探, 2007, 25: 71-81

17 解超明, 李才, 李林庆, 等. 藏北㒸塘中部首次发现泥火山. 地质通报, 2009, 28: 1319-1324

18 范卫平, 郑雷清, 龚建华, 等. 泥火山的形成及其与油气的关系. 吐哈油气, 2007, 12: 43-47

19 Milkov A V. Worldwide distribution of submarine mud volcanoes and associated gas hydrates. Mar Geol, 2000, 167: 29-42

20 Milkov A. Geological, geochemical, and microbial processes at the hydrate-bearing Håkon Mosby mud volcano: A review. Chem Geol, 2004, 205: 347-366

21 Etiope G, Milkov A V. A new estimate of global methane flux from onshore and shallow submarine mud volcanoes to the atmosphere. 
Environ Geol, 2004, 46: 997-1002

22 Milkov A V, Sassen R, Apanasovich T V, et al. Global gas flux from mud volcanoes: A significant source of fossil methane in the atmosphere and the ocean. Geophys Res Lett, 2003, 30: 1037, doi: 1010.1029/2002GL016358

23 Hedberg H D. Relation of methane generation to undercompacted shales, shale diapirs, and mud volcanoes. AAPG Bull, 1974, 58: 661-673

24 夏鹏, 印萍. 地中海海岭泥火山的构造特征及其油气意义. 海洋地质动态, 2008, 24: 1-6

25 Guliyev I S, Feizullayev A A. All about mud volcanoes, Azerbaijan, Baku. Baku: Nafta Press, 1997

26 段海岗, 陈开远, 史卜庆. 南里海盆地泥火山构造及其对油气成藏的影响. 石油与天然气地质, 2007, 28: 337-344

27 陈胜红, 贺振华, 何家雄, 等. 南海东北部边缘台西南盆地泥火山特征及其与油气运聚关系. 天然气地球科学, 2009, 20: 872-878

28 Kopf A J. Volcanoes: Making calderas from mud. Nat Geosci, 2008, 1: 500-501

29 Sawolo N, Sutriono E, Istadi B P, et al. The LUSI mud volcano triggering controversy: Was it caused by drilling? Mar Pet Geol, 2009, 26: 1766-1784

30 Manga M, Brumm M, Rudolph M L. Earthquake triggering of mud volcanoes. Mar Pet Geol, 2009, 26: 1785-1798

31 Etiope G, Feyzullayev A, Baciu C. Terrestrial methane seeps and mud volcanoes: A global perspective of gas origin. Mar Pet Geol, 2009, 26: 333-344

32 王道, 李茂玮, 李锰, 等. 新疆独山子泥火山喷发的初步研究. 地震地质, 1997, 19: 14-16

33 高小其, 王海涛, 高国英, 等. 霍尔果斯泥火山活动与新疆地区中强以上地震活动关系的初步研究. 地震地质, 2008, 30: 464-472

34 刘和甫, 梁慧社, 蔡立国, 等. 天山两侧前陆冲断系构造样式与前陆盆地演化. 地球科学一一国地质大学学报, 1994, 19: 727-741

35 戴金星. 我国煤成气资源勘探开发和研究的重大意义. 天然气工业, 1993, 13: 7-12

36 Dai J, Xia X, Qin S, et al. Origins of partially reversed alkane $\delta^{13} \mathrm{C}$ values for biogenic gases in China. Org Geochem, 2004, 35: 405-411

37 O'Nions R K, Oxburgh E R. Heat and helium in the Earth. Nature, 1983, 306: 429-431

38 Ballentine C J, Burnard P G. Production, release and transport of noble gases in the continental crust. Rev Mineral Geochem, 2002, 47: 481-538

39 戴金星, 李剑, 侯路. 鄂尔多斯盆地氦同位素的特征. 高校地质学报, 2005, 11: 473-478

40 王先涁. 稀有气体同位素地球化学和宇宙化学. 北京: 科学出版社, 1989.1-451

41 徐永昌, 沈平, 刘文汇, 等. 天然气中稀有气体地球化学. 北京: 科学出版社, 1998. 17-25

42 戴金星, 裴锡古, 戚厚发. 中国天然气地质学(卷一). 北京: 石油工业出版社, 1992. 35-87

43 Высоцкий И. В. Геология природночо газа. Москва, Недра, 1979

44 Rice D D, Claypool G E. Generation, accumulation, and resource potential of biogenic gas. AAPG Bull, 1981, 65: 5-25

45 戴金星, 陈英. 中国生物气中烷烃组分的碳同位素特征及其鉴别标志. 中国科学 B 辑, 1993, 23: 303-310

46 张士亚, 郜建军, 蒋泰然. 利用甲、乙烷碳同位素判识天然气类型的一种新方法. 见: 地质矿产部石油地质研究所, 编. 石油与天然 气地质文集(第一集). 北京: 地质出版社, 1988.48-58

47 王世谦. 四川盆地侏罗系-震旦系天然气的地球化学特征. 天然气工业, 1994, 14: 1-5

48 戴金星, 秦胜飞, 陶士振, 等. 中国天然气工业发展趋势和天然气地学理论重要进展. 天然气地球科学, 2005, 16: 127-142

49 Dai J, Ni Y, Zou C, et al. Stable carbon isotopes of alkane gases from the Xujiahe coal measures and implication for gas-source correlation in the Sichuan Basin, SW China. Org Geochem, 2009, 40: 638-646

50 Rodriguez N D, Philp R P. Geochemical characterization of gases from the Mississippian Barnett Shale, Fort Worth Basin, Texas. AAPG Bull, 2010, 94: 1641-1656

51 何登发, 陈新发, 况军, 等. 准噶尔盆地石炭系烃源岩分布与含油气系统. 石油勘探与开发, 2010, 37: 397-408

52 国建英, 李志明. 准噶尔盆地石炭系烃源岩特征及气源分析. 石油实验地质, 2009, 31: 275-281

53 李剑, 姜正龙, 罗霞, 等. 准噶尔盆地煤系烃源岩及煤成气地球化学特征. 石油勘探与开发, 2009, 36: 365-374 